Brit. J. industr. Med., 1950, 7, 37-41.

\title{
THE EFFECTS OF GRANITE ON THE LUNGS OF RATS
}

\author{
BY \\ E. J. KING, S. C. RAY, and C. V. HARRISON \\ From the Postgraduate Medical School of London \\ AND \\ G. NAGELSCHMIDT \\ From the Sheffield Research Station, Safety in Mines Research and Testing Branch, \\ Ministry of Fuel and Power
}

(RECEIVED FOR PUBLICATION SEPTEMBER 2, 1949)

Granite is one of the most frequent rock types, covering vast areas of the land surface of the earth. It is, in the language of the petrologist, a " plutonic igneous rock," which means that' it crystallized slowly under great pressure far below the surface of the earth. In consequence, its main constituent minerals are comparatively large, usually from one to several $\mathrm{mm}$. in diameter, and they can easily be recognized in a hand-specimen. Mineralogically, granite consists chiefly of felspar and quartz, smaller amounts of mica, and very small proportions of zirkon, apatite, and other minerals. On an average, granite contains twenty to thirty per cent. of quartz. Granite dust could, therefore, and does in fact, produce silicosis in man.

Granite is found in large quantities in the SouthWest of England, where a series of granite bosses stretches from Dartmoor to Lands End and beyond to the Scilly Isles. Large quarries, especially in the Bodmin Moor area and near Falmouth, produce and process granite for building stones, especially for harbour works, curbstones, etc., and for monumental stonework, chiefly tombstones. There is probably a greater dust risk in the dressing sheds than in the quarries themselves, and this seems borne out by the findings of Sutherland and others (1930). The desirability of a more up-to-date survey of silicosis incidence in granite quarries has been pointed out by Hale (1946).

Granite is also often encountered in underground mining, for instance in tin mines, and the Cornish tin industry was one of the classical areas in which silicosis was described by Haldane and others (1904).

A medical and environmental survey has recently been carried out in a Cornish tin mine (Hale and Perry, 1949), and it seemed desirable to supplement the work in this field by animal experiments. Under present-day conditions of dust control, it is nearly impossible to collect sufficient air-borne dust from a tin mine for such work. The granite in which the tin lodes occur is, however, almost identical in composition with the granite found in the quarries, and the sample used for the present work was prepared from dust collected from beams and rafters of the working sheds from Quarry "A" in Cornwall. We are grateful to Dr. L. W. Hale for providing this sample.

\section{Materials and Methods}

Granite Dust.-A few pounds of the rafter dust were suspended in water and, after two washings and the addition of dilute ammonia, a suspension deflocculated at $p \mathrm{H} 8$ was obtained. A fraction below $2 \mu$ equivalent diameter was separated by three successive decantations. The combined suspensions were flocculated with hydro-

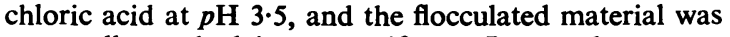
repeatedly washed in a centrifuge. It was then ovendried and lightly crushed. Microscopic inspection showed it to contain no particles over $5 \mu$ and the bulk appeared to be below $1 \mu$. A microscopic count of 800 particles was made and the mass distribution calculated from it (see Table).

TABLE

SIZE DISTRIBUTION OF CORNISH GRANITE QUARRY RAFTER DUST *

\begin{tabular}{ccc|c|c}
\hline \multicolumn{3}{c|}{$\begin{array}{c}\text { Particle size } \\
\text { in } \mu\end{array}$} & \multicolumn{2}{c}{ Percentage of particles } \\
\cline { 3 - 5 } & & By number & By mass (calc.) \\
\hline Under & 0.5 & $\ldots$ & 34 & 2 \\
, & 1.0 & $\ldots$ & 87 & 30 \\
, & 2.0 & $\ldots$ & 99 & 80 \\
, & 3.0 & $\ldots$ & 100 & 100 \\
\hline
\end{tabular}

* Median particle size : $0.6 \mu$ by number, $1.3 \mu$ by mass.

Analysis.- $X$-ray diffraction analysis indicated the presence of minor amounts of kaolin and possibly mica in addition to the main constituents felspar and quartz. A comparison of the relative intensities of $x$-ray lines 


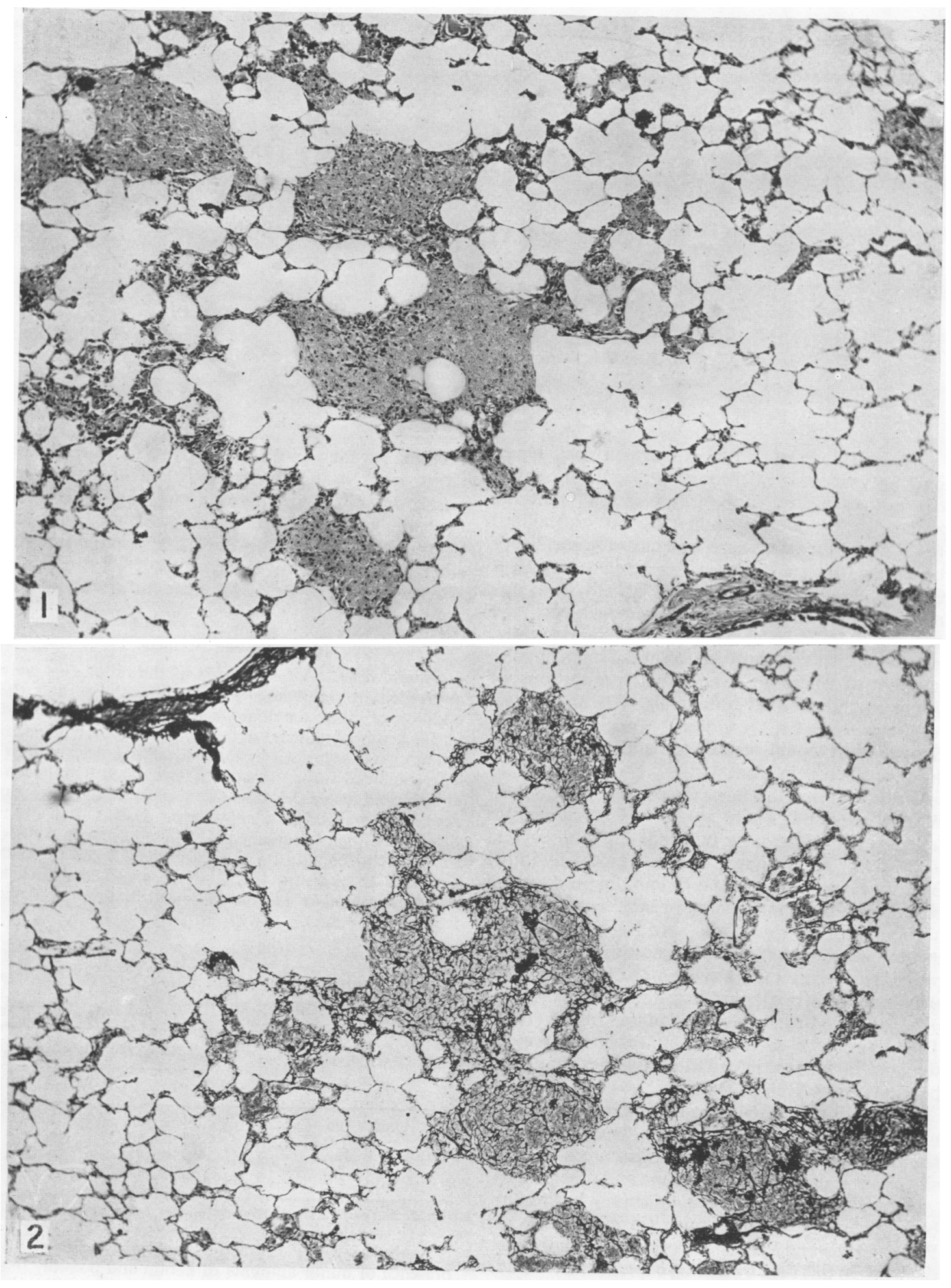

FIG. 1.- Rat lung, 102 days after injection of dust, showing foci of dust cell reaction. (Hæmatoxylin
and eosin, $x$ 77).

FIG. 2.-Serial section to Fig. 1. Silver impregnation showing loose tangled network of reticulin (x 77). 


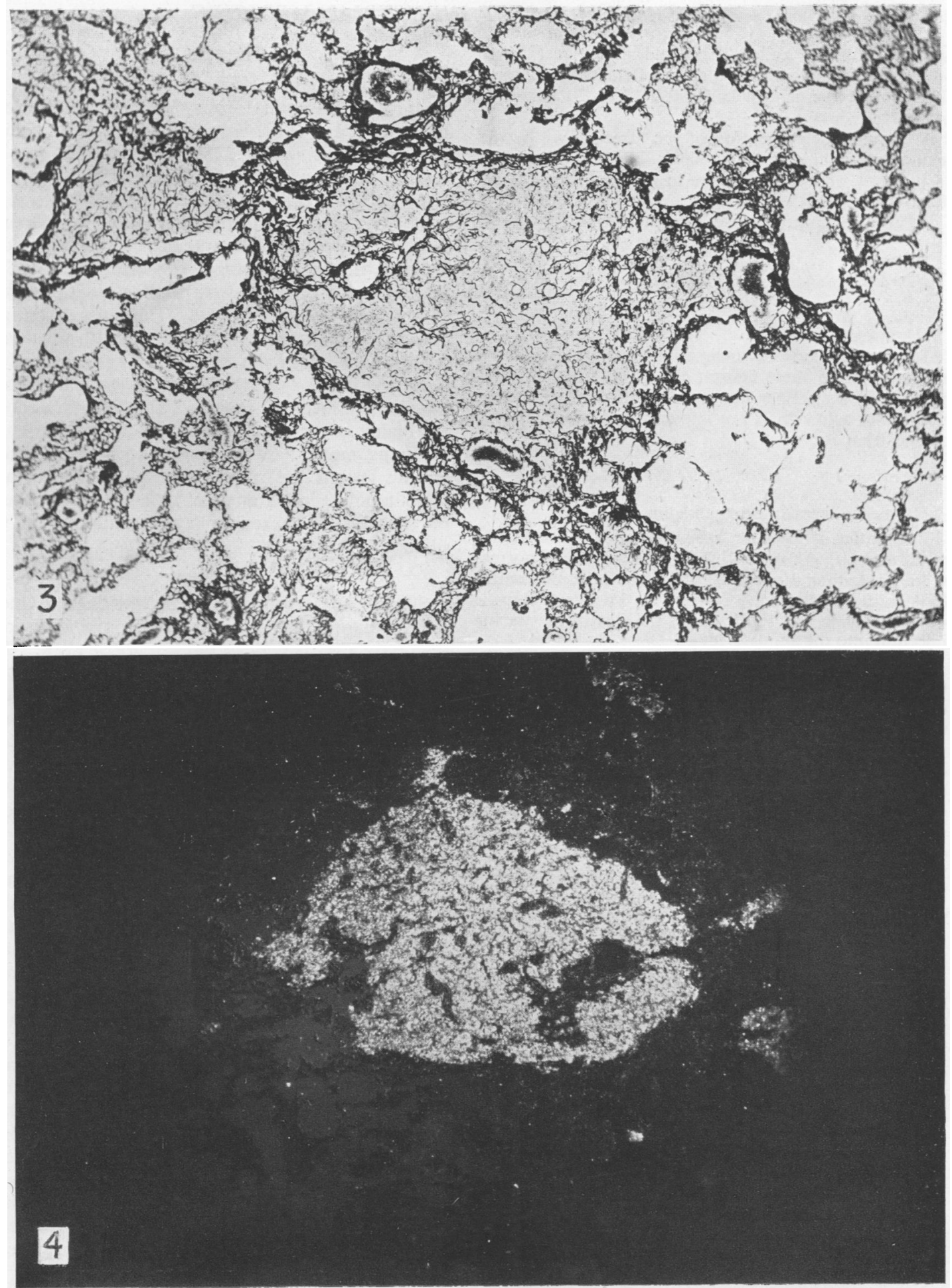

Fig. 3.-Rat lung, 252 days after injection of dust, showing a single nodule with a tangled network of reticulin, no more severe than in Fig. 2. (Silver impregnation, $x$ 77.)

Fig. 4.-Serial section to Fig. 3 photographed by dark-ground illumination to show the amount of dust present (x 77). 
at $3 \cdot 34 \AA$ (quartz and felspar) and at $3 \cdot 21 \AA$ (felspar only) of the sample and of a series of standard mixtures showed that the sample contained 15 to 20 per cent. of quartz.

A chemical determination of the 'free silica' by the semi-micro-modification of Shaw's (1934) method gave 16 per cent. of quartz, a figure in good agreement with the $x$-ray estimate.

Partial chemical analysis gave the following figures :

$$
\begin{array}{lcccccr}
\mathrm{SiO}_{2} & \ldots & \ldots & \ldots & \ldots & \ldots & 64 \cdot 0 \\
\mathrm{Al}_{2} \mathrm{O}_{3} & \ldots & \ldots & \ldots & \ldots & \ldots & 16 \cdot 6 \\
\mathrm{~K}_{2} \mathrm{O} & \ldots & \ldots & \ldots & \ldots & \ldots & 5 \cdot 0 \\
\mathrm{Na}_{2} \mathrm{O} & \ldots & \ldots & \ldots & \ldots & \ldots & 3 \cdot 7 \\
\text { Ignition loss } & \ldots & \ldots & \ldots & \ldots & 4 \cdot 1
\end{array}
$$

The proportion of quartz cannot be calculated accurately from these figures, chiefly because the composition of the felspar (an equal mixture of orthoclase and albite) below $2 \mu$ is not known. Approximately the composition is :

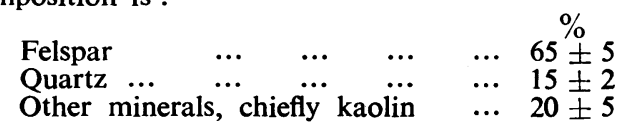

Preparation of Dust for Animal Injection.-An amount of the dust $(1.5 \mathrm{~g}$.) was well shaken with $30 \mathrm{ml}$. of normal saline containing 3 per cent. of milk in a $50 \mathrm{ml}$. conical flask covered with a rubber cap. This 5 per cent. suspension was made and sterilized on the day of its use for injection into the animals' lungs.

Experimental Procedure.-The animal experiments were conducted along the lines previously described (Belt and King, 1945 ; King and others, 1949) following the technique of Kettle and Hilton (1932). The rats were from the M.R.C. black and white strain previously employed. Their average weight was $250 \mathrm{~g}$. They were lightly anæsthetized with ether. The sterile dust mixture was well shaken in its conical flask, and $1.5 \mathrm{ml}$. was withdrawn through the rubber cap into a $5-\mathrm{ml}$. syringe fitted with a short, sharp needle (1 inch) of 22 gauge. This corresponded to $75 \mathrm{mg}$. of the granite mixture. The trachea was exposed by blunt dissection, the needle was inserted into the trachea, and the mixture was injected into the lungs. To obtain good dispersion the suspension was kept agitated right up to the moment of injection and was emptied quickly to prevent sedimentation. A small amount was occasionally regurgitated through the nostrils (but it is thought that at least $60 \mathrm{mg}$. of mineral dust was injected into each animal's lungs). Operation casualties were very few.

Sixteen rats were used for the experiment, and they either died or were killed at intervals up to a year, when any animals which remained were killed. The lungs, together with part of the trachea, were removed, distended with formol saline, fixed, embedded, and sectioned in accordance with our previously described techniques. Sections were made across the mid-region of both lungs and included the hilar lymph glands. Four sections were cut from each block: for hæmatoxylin and eosin ; Gordon and Sweet's (1936) silver impregnation for reticulin; Irwin's (1934) microincineration; and for microincineration plus $\mathrm{HCl}$ treatment to remove all but the siliceous component of the ash.

\section{Results}

There was a trace of reticulinosis in one rat at 28 days; but apart from this the first lesions appeared at about 100 days in the form of focal dust cell collections with much dust and a loosely tangled reticulin network. These lesions seemed to persist constantly up to $\mathbf{2 5 0}$ days with no significant qualitative change. They did not become collagenous, although they tended to become more rounded in the later stages of development. The hilar lymph nodes showed similar reactions, but with slightly denser reticulin. These tissue changes are illustrated in figs 1 to 4 , which can with advantage be compared with figs. 1 and 2 of the paper by King and others (1949), which show typical silicotic nodules produced by quartz. The silicotic nodules are highly collagenous, large, and dense in animals surviving more than 200 days. In contrast, these granite lesions are smaller, much less dense, and contain only a loose tangle of reticulin fibrils instead of the densely-packed collagen exhibited by the silicotic nodules.

\section{Discussion}

Silicosis in Cornish granite workers develops more slowly than in sandstone workers, and is usually seen only after twenty or more years of work. The $x$-ray shadows show a fine mottling with reticulation and linear striations, and are not as discretely nodular as the silicotic nodules of sandstone workers (compare Gardner, 1938; Middleton, 1936 ; Hale, 1946, 1949). This is probably related to the low quartz content of the dust (15 per cent. quartz ${ }^{*}, 65$ per cent. felspar, and 20 per cent. kaolin and mica).

Gardner (1920) made an experimental study of the lesions produced by the inhalation of Vermont granite dust by guinea-pigs and rabbits. The dust employed was obtained from the exhaust system of a cutting shed, and consisted of 33 per cent. quartz and 66 per cent. felspar and mica. The maximum reaction of this dust in the lungs of animals over a period of two years did not even approximate to the nodular response to pure silica, such as quartz. It consisted of focal collections of dust-filled phagocytes within groups of air sacs and in the areolar tissues along the lymphatics. There was thickening of the arteries and larger septa which was more cellular than fibrous. The focal collections of dust in the lungs assumed the appearance of silicotic nodules in a few cases in the presence of infection; but even these were only loosely reticular in structure and were not hyaline as in the case of silicotic

\footnotetext{
* Shaw (1939) found that Cornish granite dust $>5 \mu$ produced by drilling, had more quartz than the original granite. Our data appear to show the opposite. The original granite has about 30 per cent. quartz, and the $>2 \mu$ fraction only 15 per cent.
} 
nodules. In the lymphatic glands of the animals surviving longest the reaction was more pronounced, some nodules having been formed which were mildly fibrous in structure. In further experiments with intravenous injections of granite dust similar results were obtained.

Our own work, and that of Gardner, suggest that granite dust produces only a mild reaction in the lungs of animals; and that the amount of tissue reaction is rather less than might be expected from the quartz content of the dust. The tissue response is of a type rather similar to that produced by South Wales shale dust and mixtures of shale dust and quartz (Belt and King, 1945; King, 1947). The shale dust contained kaolin and mica in addition to quartz, and the impression was gained that these silicates had an inhibiting effect on the fibrogenic action of the quartz, possibly because of their contained aluminium which was releasable from the powdered shale when suspended in saline.

Gardner made the supposition that the felspar and mica of his granite had a neutralizing action on the quartz contained in it ; and the present work appears to reinforce that conclusion. Cornish granite dust has produced only reticulinosis in the lungs of rats, and appears to be only about as fibrogenic as shale dust and mixtures of quartz with mica and kaolin (Belt and King, 1945; King and others, 1948). These findings are in keeping with the observations of Russell and others (1929) on Vermont granite workers, of Sutherland and others (1930), and Hale (1949), on Cornish granite workers, and of numerous other investigators, that granite dust does not furnish nearly as serious a risk to the health of workers as do other industrial dusts of higher free silica content.

\section{Summary}

The pathogenicity of a sample of Cornish granite, prepared from dust collected from beams and rafters of the working shed of a quarry, has been tested in rats by the intratracheal injection of a suspension of the powder into the lungs of rats. This granite dust, a mixture of quartz, felspar, and mica, produced only a mild reticulin reaction not comparable with the silicosis produced by quartz.

We are grateful to the Medical Research Council for a grant to defray the expenses of this investigation. Miss V. Pash, Mr. C. G. Johnston, and Mr. W. Weedon rendered valuable technical assistance, and Mr. E. V. Willmott prepared the photomicrographs.

\section{REFERENCES}

Belt, T. H., and King, E. J. (1945). M.R.C. Spec. Rep. Ser. No. 250 , p. 29 . London.

Gardner. L. U. (1920). Amer. Rev. Tuberc., 4, 734 (1938) in "Silicosis and Asbestosis" by A. J. Lanza. Oxford. p. 257. London.

Gordon, H., and Sweets, H. H., Jr. (1936). Amer. J. Path., 12; 545. Haldane, J. S., Martin, J. S., and Thomas, R. A. (1904). Report on the Health of Cornish Miners, Cd. 2091, H.M.S.O. Lopdon. Hale, L. W. (1946). Thorax, 1, 71 . (1949). "Memorandum on the Cornish Granite-dressing Industry," Medical Research Council. London. - , and Perry, K. M. A. (1949). Private communication.

Irwin, D. A. (1934). Canad. med. Ass. J., 31, 135.

Kettle, E. H., and Hilton, R. (1932). Lancet, 1, 1190.

King, E. J. (i947). Hccup. (1932). 26.

King, E. J. (1947). Occup. Med., 4, 26. Bact., 60, 435 .

- - Ray, S. C., and Harrison, C. V. (1949). In the press.

Middleton, E. L. (1936). Lancet, 2, 59.

Russell, A. E., Britten, R. H., Thomson, L. R., and Bloomfield, J. J. (1929). U.S. Publ. Hith. Bull., 187.

Shaw, A. (1934). Analyst, 59, 446.

(1939). Proc. S. Wales Inst. Engrs., 55, 96.

, Leport on Silicosis Amongst Granite Workers. H.M.S.O. 